\title{
Nieuchwytność nieuchronnego plagiatu
}

Piotr Michałowski

TEKSTY DRUGIE 2019, NR 1, S. 217-228

DOI: 10.18318/td.2019.1.14 | ORCID: 0000-0002-8716-9655

$\mathbf{N}$ ie ma tekstów całkowicie niezależnych. Każdy, nawet zrodzony z najlepszej woli i wysiłku innowacji, zawiera bardziej lub mniej słyszalne echa innego. Także powyższe twierdzenie, które w dziejach języka i literatury pojawiało się wielokrotnie, by stać się oczywistością w świetle dekonstrukcji, gramatologii i teorii palimpsestu. Tytuł książki Macieja Jakubowiaka streszcza je formułą wziętą od Hegla Nieuchronny plagiat', która zapowiada treści dobrze zadomowione we współczesnych teoriach; natomiast dopiero podtytuł zwiastuje rozdroże widoczne w konfrontacji dwóch perspektyw: Prawo autorskiew nowoczesnym dyskursie literackim. Zapowiada bowiem konflikt, w który wikła się każda jednostka pisząca cokolwiek i w jakiejkolwiek dziedzinie, wraz z całą wspólnotą pisma. Problem, dotychczas zaniedbany jako przedmiot analiz interdyscyplinarnych, doczekał się wreszcie rzetelnego, a zarazem imponującego rozmachem opracowania.
Piotr Michałowski

- dr hab., kierownik

Zakładu Teorii i Antropologii Literatury Uniwersytetu Szczecińskiego. Ostatnio opublikował m.in. książki: Mikrokosmos wiersza. Interpretacje poezji współczesnej (2012) iZ narożnika mapy (2017) oraz zredagował tom zbiorowy Od pióra do sieci.Zmienne media literatury (2015).

1 M. Jakubowiak Nieuchronny plagiat. Prawo autorskie w nowoczesnym dyskursie literackim, Wydawnictwo IBL PAN, Warszawa 2017. 
Książka nie jest podręcznikiem ani dla prawników, ani dla ludzi pióra, gdyż nie zawiera żadnych „instrukcji obsługi” tekstu - ani dla notorycznych plagiatorów, ani dla ich urzędowych tropicieli. A jednak warto ją polecić jako lekturę obowiązkową wykonawcom obu profesji; uwrażliwi bowiem prawnika na problemy literatury a literata na aspekty prawne jego działalności. W obydwu sytuacjach będzie to lekcja pokory wobec języka jako narzędzia komunikacji i wobec ontologii tekstu, prowadzona na spornym pograniczu language i parole, która zapewne skłoni obie strony do kontynuacji odwiecznego dialogu, rozszerzy jego horyzont, ale zarazem odnowi mury wzajemnej obcości. Badacz pozostawia bowiem kilkusetletni spór bez rozstrzygnięcia, zresztą nie zgłasza nowej propozycji ugody ani nie podejmuje się mediacji, lecz stawia sobie cel czysto poznawczy. Wydaje się jak najdalszy od publicystycznego zaangażowania, jednak dostarczając bogatego materiału historycznego, pobudza do wielostronnych refleksji nad współczesną sytuacją literatury i całej kultury pisma, wskazując pośrednio na wszechwładzę prawa zjego roszczeniami do normatywizacji świata. Tezy książki i wnioski czyhają więc w cieniu zajmującej opowieści o losach słowa pisanego ijego przygodach z prawem; niekiedy wyrażane w skromnych komentarzach krytycznych, ale najczęściej niedopowiedziane, choć implikowane lub bezstronnie otwarte na opinie czytelnika.

Praktyka pisarska zmusza do milczącej akceptacji sprzecznych prawd dotyczących genezy utworu i jego własności: każdy tekst jest zarazem wspólny, czyli niczyj i własny lub cudzy. Godzimy się na dychotomię ujęć filozoficznych i ekonomiczno-prawnych, jak fizycy uznający korpuskularno-falowy dualizm natury światła, a sprzeczność ujawnia się jedynie przy podpisywaniu umowy z wydawcą. Rutyna wynikająca z niechęci do prawniczego żargonu powstrzymuje głębszą refleksję, co może zmienić lektura tej książki, choć w przyjętej w niej perspektywie badawczej stroną czynną konfliktu, ale niekoniecznie bohaterem pozytywnym, pozostaje „nowoczesny dyskurs literacki”, próbujący skruszyć prawniczy konserwatyzm. Przedstawiając założenia metodologiczne rozprawy, badacz deklaruje:

Zamierzam udowodnić, że uwzględnienie kontekstu prawnoautorskiego w znaczny sposób może się przyczynić do pełniejszego zrozumienia nowoczesnych dyskusji dotyczących tego, czym jest literatura. (s. 57)

Fascynującej ekspedycji przez grząskie pogranicze oryginalności i plagiatu musi towarzyszyć samoświadomość uwikłania wędrowca, który już 
w punkcie wyjścia autotematycznie relatywizuje autorstwo swej książki w długim szeregu podziękowań osobom, które przyczyniły się do jej powstania (z uwzględnieniem cierpliwości członków rodziny i psów), by spuentować toposem skromności: „wszyscy jesteśmy autorami tej książki” (s.10). W wyliczeniu adresatów i powodów wdzięczności zwraca uwagę zagadkowy koncept: podziękowanie bratu „za każdą postawioną w tej książce literę «y»" (s. 10). Nie wiadomo, o jaką pomoc czy dywersję stylistyczną tu chodzi, ale zdanie to nasuwa myśl o korekcie, która zresztą również znalazła się na liście podziękowań. Otóż często zapomina się o wkładzie twórczym korektorek w ostateczną formę językową dzieła (toteż ja z góry dziękuję), niekiedy rodzącym teksty drugie, trzecie i dalsze, czyli rozmnażającym wersje i zapewniającym śledczą pracę edytorom ewentualnych przedruków. A zatem nawet czysto "techniczne" poprawki uczą pokory, ograniczając indywidualne „autorstwo"; pomijam tu ingerencje cenzury, służące nie doskonaleniu tekstu, lecz osłabianiu jego mocy.

W horyzoncie rozprawy znalazł się rozległy obszar światowych badań interdyscyplinarnych nad dwojakiego rodzaju związkami prawa z literaturą, projektowanych przez Dolina, Posnera i Warda, oraz badania kulturowe zainicjowane przez Foucaulta, Boyle'a i Saint-Amoura. Po pierwsze, chodzi o „prawo w literaturze", czyli dzieła będące wykładnią prawa, komentujące je lub traktujące jako metaforę, a reprezentacja tych ostatnich jest najbogatsza: Dickens, Zola, Dostojewski, Kafka, Camus. Po drugie - o prawo (a zwłaszcza narracje sądowe) traktowane jak literatura - ujęcie popularne w kulturze amerykańskiej.

W obszernym Wprowadzeniu badacz przedstawia paradygmat prawa autorskiego, główne tendencje w „dyskursie prawnoautorskim” oraz przełomowe akty legislacyjne: od angielskiego Statutu Anny z 1710 roku po współczesne ACTA, wokół których przed paru laty rozgorzał ostry spór. Najistotniejsze wydaje się wskazanie dwóch typów prawa, które wyznaczają opozycyjne kierunki legislacji, a tym samym źródła konfliktów: droit d'auteur - chroniące przede wszystkim własność twórcy, i copyright - dające prawo do rozpowszechnienia, a więc reprezentujące teoretycznie interes czytelnika, a praktycznie - wydawcy.

Tu pozwolę sobie na dygresję, ponieważ niestety niewiele miejsca poświęca badacz relacji prawnej między autorem a wydawcą, choć zauważa, że dziś właśnie ten obszar wydaje się najbardziej sporny, obejmując strefę graniczną między prawami twórcy a wspólną własnością odbiorcy. Zapewne, można uznać, że to problem zasługujący na osobną monografię - niekoniecznie 
skazaną na odmowę wydania z powodu niechcianej treści i konfliktu interesów. Tymczasem jednak codzienna praktyka twórczości naukowej nie pozwala dla zawieranych układów przewidzieć skutków w mglistej przyszłości projektowanej przez umowy wydawnicze, zresztą zwykle spisywane ex post i traktowane jak pozbawiony konsekwencji biurokratyczny rytuał, którego koszty zapewne przekraczają przewidziane trzycyfrowe honoraria autorskie. Prawo wykazuje daleko idącą przezorność, którą można postrzegać jako nadgorliwość, ale uwzględnia różne sytuacje i zakłada zdolność przystosowania kształtu umowy do konkretnego przypadku.

Zapewne każdy autor gromadzi w pęczniejącym skoroszycie podpisane przez siebie umowy i jeśli zada sobie trud analizy tego archiwum, dostrzeże w nich interesujące zmiany, które mogą dowodzić korzystnej ewolucji formy i treści. Wprawdzie kwoty honorariów niezmiennie odbiegają od norm światowych, ale zmniejsza się rozmiar dokumentu, ograniczony dziś do dwóch stron. Świadczy to o bardziej selektywnym podejściu do treści ustawy i analitycznym zastosowaniu go do przedmiotu umowy. Wciąż jednak pojawia się pewien zapobiegliwie wykreowany nadmiar dotyczący zakresu dystrybucji, który obejmuje nie tyle adresowane do autora obietnice sławy, ile wielkościowe urojenia wydawcy, przewidującego -

utrwalenie i zwielokrotnienie dowolną techniką, w tym techniką drukarską, reprograficzną, cyfrową oraz na nośnikach magnetycznych, optycznych i elektronicznych, w szczególności w formie książki elektronicznej (e-book), w nieograniczonej liczbie egzemplarzy, wydań i dodruków $[\ldots]^{2}$

Pojawiają się wyliczenia znacznie dłuższe, obejmujące „technikę analogową lub cyfrową",,,nośniki audio i video”, ,nośniki światłoczułe lub optyczne”, "dyski”, ,kości pamięci”, , ,bazy danych”, ,, serwery lub inne urządzenia i systemy” "stacje naziemne”, ,pośrednictwo satelity”, „sieci kablowe, telekomunikacyjne lub multimedialne". Łatwo zauważyć, że wystarczyłoby poprzestać na pojemnej formule „dowolna technika”, gdyż specyfikacja prospektywna okaże się i tak niepełna po każdym nowym wynalazku, zwłaszcza że ustawodawcy nie wykazują w tej mierze profetyzmu na miarę Lema. Godna podziwu futurologia prawnoautorska wynika z uzasadnionej zapobiegliwości, która jest jednak troską o interes wydawcy, a nie autora. Fantazja zleceniodawców

2 Cytuję autentyczną Umowę licencyjną, a potem wyliczam formy rozpowszechnienia z innej Umowy o dzieło. Obie podpisałem z podmiotami, którym zapewniam anonimowość. 
wprowadza w bezkresy technicznego raju rozpowszechnienia i nawet w sytuacjach, gdy chodzi o zwykłą prelekcję przeprowadzoną w powiatowym LO (a tego właśnie dotyczy cytat), zwiastuje kosmiczny rozgłos wydarzenia, choć pośród metod wykorzystania tekstu nie wymienia ekranizacji w Hollywood. W tak śmiałym projektowaniu życia wiecznego autora nie widzę niczego złego, ale tymczasem jedynym skutkiem cytowanej umowy była skromna wzmianka w prasie, jeśli pominąć ważniejszy od niej, a nie objęty umową, ślad w pamięci klasy i nauczyciela.

Doświadczaną często dysproporcję między legislacyjną pedanterią (wynikającą z braku rozsądku lub megalomanii) a pracą twórcy możemy postrzegać raczej jako drogę do Kafkowskiego Zamku niż przejaw troski o zabezpieczenie naszych autorskich „dóbr intelektualnych”. Umowa staje się jednostronnym dyktatem³; za przeciwwagę przeważnie pustych obietnic nie może bowiem służyć ciężkie i z pełną odpowiedzialnością podpisane zobowiązanie autora, który niezmiennie musi oświadczyć, że „utwór jest wynikiem jego oryginalnej twórczości" - cokolwiek formuła ta znaczy i do czegokolwiek się odnosi, gdyż bywa stosowana także wobec tekstów ewidentnie zależnych, takich jak recenzja czy przekład. Filozoficzno-literackie dylematy oryginalności i nieuniknionej repetycji kulturowej mogą obciążać jedynie sumienie autora, natomiast nie znajdują żadnego odbicia w sztywnym rytuale prawnym, odgrywanym za pomocą bezkrytycznie używanego języka, złożonego z pojęć, które pragmatycznie uchylają zawiłości poznawcze i fingują sferę oczywistości.

Takie refleksje może nasuwać lektura znakomitej książki, która eksponuje głównie kwestie sporne, uświadamia relatywizm pojęć i paradoksalny status literatury, ale czyni to na rozległym tle całej systematycznie wyłożonej problematyki prawnoautorskiej, toteż powinna zainteresować zarówno czynnego, jak i biernego użytkownika dowolnego tekstu werbalnego.

Rozdział Wymyślanie prawa jest rzetelnie przeprowadzonym przeglądem chronologicznym regulacji prawa autorskiego w Europie i w Polsce - począwszy od przywilejów drukarskich, po konwencję berneńską z 1886 roku, na gruncie której formułowane są współczesne akty prawne. Co ciekawe, początkowo chodziło nie o dobro autora, lecz o obciążenie go odpowiedzialnością

Asymetrię praw i obowiązków między stronami umowy satyrycznie wyostrza Michaił Bułhakow w Powieści teatralnej (przeł. Z. Fedecki, Warszawa 1994, s. 69-70), w której pojawia się motyw umowy o dzieło, obejmującej kilkudziesięciopunktowe wyliczenie z anaforą "Autor nie ma prawa..." Natomiast w swoich zbiorach posiadam kuriozalną umowę, która wprawdzie nie przewiduje żadnego honorarium, ale zawiera groźbę jego potrącenia w przypadku konieczności dokonania przekraczających pewien limit zmian w tekście. 
za ewentualne społeczno-polityczne skutki druku. Niemniej fundamenty prawa stworzyli filozofowie, zwłaszcza Kant, który za nadawcę w procesie publikacji uznał autora, przydzielając drukarzowi jedynie rolę medium. Najistotniejsze okazało się odróżnienie autorskiego czynu (opus) od książki jako przedmiotu materialnego (opera), które z kolei Fichte nazwał odpowiednio dwoma aspektami utworu: ideacyjno-formalnym i materialnym. Dziwi więc, że ta klasyczna opozycja bywa dziś zacierana, przez co powstają nieporozumienia $\mathrm{w}$ dyskursie publicystycznym o książce i czytelnictwie, gdyż najgłośniej wybrzmiewa naiwnie jednostronna teza podporządkowująca humanistykę absolutyzmowi (bynajmniej nie „oświeconemu”) ekonomii w sloganach: „książka to też towar”, a środowisko, w którym funkcjonuje, to po prostu "rynek”.

$\mathrm{Z}$ następnego rozdziału Badania literackie na ustugach legislacji dowiadujemy się, że prawodawstwo nie tylko podążało za ewolucją idei autorstwa, lecz również wspólnie z literaturoznawstwem ją kształtowało. Otrzymujemy imponujący przegląd koncepcji wypracowanych przez różne metodologie, obejmujący m.in. ewolucjonizm i krytykę genetyczną, która w przeciwieństwie do pozytywistycznego genetyzmu nie dąży do ustalenia wersji kanonicznej tekstu, lecz głównie śledzi proces tworzenia, a więc powstawania rękopisu. Szczegółowe analizy dowodzą, że dyskurs prawnoautorski w wielu punktach przecina się z różnymi kierunkami literaturoznawstwa: badaniami genealogicznymi, strukturalizmem i oczywiście dekonstrukcją.

Znaczną część książki stanowi erudycyjny przegląd stanowisk w dyskusjach, sporach, polemikach i procesach sądowych wokół prawa własności intelektualnej, które wybuchały przy okazji publikacji konkretnych utworów (jak wywołany drukiem przekładu Pracowników morza Wiktora Hugo), ale okazały się płodne jako precedensy kształtujące zarówno postawy autorów i krytyków, jak i tory działań legislacyjnych. Obszernymi komentarzami krytycznymi opatruje badacz artykuł Kraszewskiego o kradzieży literackiej (wyprzedzający poglądy Derridy), prace Bradleya o „wpływach” i „zależnościach", Lowesa teorię oryginalności, prace Borowego o dialektyce naśladownictwa oraz Irzykowskiego, któremu poświęca najwięcej uwagi jako autorowi głośnych artykułów Rabunek prawa autorskiego i Plagiatowy charakter przełomów literackich $w$ Polsce.

Niewątpliwie poglądy Irzykowskiego, parokrotnie sytuacyjnie przezeń modyfikowane i w sumie tak niekonsekwentne, że wikłają się w samozaprzeczenia, trudno byłoby ułożyć zarówno w przydatną formułę prawnoautorską, jak i w spójną teorię tekstu czy dyskursu, wykazują największy radykalizm 
w rozstrzyganiu kwestii oryginalności i naśladownictwa, uznając za plagiat nawet związki frazeologiczne. Podważają one sens nie tylko podejmowania jakichkolwiek prób legislacji, ale i uprawiania sztuki słowa. Skrajne stanowisko, sugerujące, że cała literatura nie jest niczym innym jak ciągiem plagiatów, ponieważ w każdym dziele dałby się odnaleźć wpływ innego dzieła, a cała kultura polega na różnych formach naśladownictwa i przetwarzania, wydaje się jednak parodią dyskursu prawnoautorskiego, gdyż prowokacyjnie doprowadza go do absurdu i mogło być postrzegane jako sianie zamętu albo wręcz chuligaństwo intelektualne. Szkoda że w postawie Irzykowskiego badacz widzi głównie publicystyczne zaangażowanie, a trochę nie dostrzega felietonowego dystansu i nie wspomina o takich reakcjach jak autoironiczny komentarz Tuwima w Kwiatach polskich, który prawdopodobnie nawiązuje właśnie do ekstremalnego stanowiska w omawianym sporze:

Wracam do willi. A po drodze

Był sad. BY Ł SAD. Zauważ plagiat,

Dwusłowy wprawdzie, lecz bezsporny.

Lecz jakaż poetycka magia

Ten fakt wczaruje w nowe formy,

Oryginalne, własne? Rad bym,

Ale nie będę usiłował

Dwu słów ubierać w nowe słowa.

Piszę: „był sad”, bo właśnie sad był: ${ }^{4}$

W tej dygresji autotematycznej, będącej zarówno świadomym nawiązaniem do cytowanego Pana Tadeusza, jak i pośrednio usprawiedliwieniem każdego użytkownika języka, który, stosując nawet najprostsze struktury syntaktyczne, skazany jest na powtarzanie cudzych słów, można bowiem dosłuchać się echa międzywojennych polemik wokół nieuchronności plagiatu.

Borowy natomiast przyznaje prawo do repetycji tylko mistrzom, z czym Jakubowiak polemizuje, ale w krytyce tego stanowiska można pójść dalej, podważając jeden z mechanizmów życia literackiego, jakim jest ustanawianie autorytetu pisarza, a więc pozycji kogoś, komu „wolno więcej”. Odbywa się to najpierw za sprawą krytyki literackiej, a potem historii literatury, która wielkość wykreowaną przez tę pierwszą niekiedy po latach koryguje. Paradoks polega na tym, że początkowo źródłem wielkości staje się wybitne

4 J. Tuwim Kwiaty polskie, wstęp i oprac. P. Michałowski, Kraków 2004, S. 103. 
dzieło, a potem relacja przyczynowo-skutkowa zostaje odwrócona i powodem uznania dla dzieł następnych nie musi być już ich wielkość, lecz wyłącznie autorstwo. W przypadkach skrajnych nawet jedno wcześniejsze arcydzieło promuje całą serię późniejszej grafomanii. Takie zjawiska można wskazać w literaturze najnowszej: bezkrytycznego zaufania i bezwarunkowego kredytu, a w efekcie wymuszonych przez koniunkturę zachwytów nad słabym utworem uznanego mistrza.

Ponadto i Borowy, i Jakubowiak jako jego krytyczny komentator dotykają tu jeszcze innych kwestii. Pierwszą jest żywotność dzieła, drugą - jego doniosłość. Pierwsza nie sprowadza się tylko do popularności autora i jego pozycji na rynku książki, bo w równym stopniu decydują o niej okoliczności instytucjonalne: miejsce publikacji i efektywność działań promocyjnych. Żywotność niekoniecznie odpowiada doniosłości, czyli miejscu na pośmiertnym parnasie historii literatury, czego dowodzą choćby liczni autorzy z międzywojnia.

Kolejne rozdziały skupiają się na sporach wokół konkretnych utworów, które jednak znaczą przełomy w ewolucji prawa autorskiego, a więc nie jest to wyłącznie pitaval zawierający studia sensacyjnych przypadków i skandali. Wreszcie badacz dociera do współczesności, by w rozdziale Wywrotowa legislacja przedstawić koncepcje autorstwa w myśli Derridy i metaliterackiej fikcji Parnickiego. Na koniec zastanawia się nad przyszłością prawa autorskiego, rozpatrując różne drogi jego możliwej ewolucji. Ale zarówno świetnie zrelacjonowane dzieje, jak futurologia, stanowią dopiero erudycyjne tło dla niepokojącej sugestii zawartej w tytule książki a uporczywie powracającej przy omawianiu niemal każdego epizodu z konfliktowego współżycia literatury z prawem.

Jako kluczowe dla prawa autorskiego wskazuje badacz sformułowane przez Hegla pojęcie „uzewnętrznienia”, które enigmatyczny problem faworyzowanej przez romantyków oryginalności myśli przemieszcza na poziom empirii - językowej ekspresji i zapisu. I wreszcie - skrajne przeświadczenie niemieckiego filozofa o "nieuchronności plagiatu”, które stało się głównym wątkiem rozprawy. Początkowo wydaje się jedynie nośnym hasłem jako narzędzie efektownej prowokacji, lecz w miarę lektury obrasta w liczne konteksty uzasadniające jego powagę i wagę jako fundamentalnej kwestii w sporze o istotę własności intelektualnej, sporze, który toczy się na grząskim gruncie definicji tekstu. Granice między powtórzeniem a innowacją pozostają nierozstrzygnięte, jednak wybór hasła „nieuchronny plagiat" na tytuł całej pracy sugeruje, że jej autor opowiada się za jedną z biegunowych opcji - tą, która własność tekstu kwestionuje, ponieważ neguje oryginalność jako utopię. $\mathrm{Na}$ 
szczęście jednak lektura książki nie upoważnia do takiej generalizacji. Tytułowa teza, choć zacytowana bez cudzysłowu, motywowana jest modalnością historycznego cytatu, lecz bez sugestii ironicznego dystansu. Względność twierdzenia o nieuniknionym powtórzeniu wynika z pamięci kultury, której istotą jest paradoksalnie amnezja dotycząca źródeł.

Owa nieuchronność wynika, w pierwszej kolejności, ze specyfiki nauki jako procesu przyswajania, definiowanego przez powtórzenie. Procesy uzewnętrzniania i uwewnętrzniania zachodzą bezustannie, a wszelkie próby ich kontrolowania i ustalania pierwotnych właścicieli idei są skazane na niepowodzenie. (s. 110-111)

Jako swoisty manifest nieuchronności plagiatu badacz omawia Ziemie jałowa Eliota - poemat zdominowany przez cytaty, parafrazy i aluzje, utwór bliski centonowi, a jednak mieszczący się w granicach prawa, choć jego autorstwo może budzić największe obiekcje, nawet bez uwzględnienia śladów znacznej ingerencji w tekst, dokonanej przez Pounda. Eliot, którego nikt o plagiat nie oskarżył, choć poeta, czerpiąc z tradycji, naruszył wyznaczoną przez konwencję berneńską granicę „domeny publicznej”, wspierał swe dzieło eseistyką, stwierdzając, że zapożyczenie jest źródłem innowacji, i zgłaszał postulat „twórczej kradzieży”.To niewątpliwie przykład najbardziej skrajny, a więc inspirujący do najdalej posuniętego zakwestionowania idei autorstwa.

Trochę dziwi, że w swych rozważaniach autor pracy pominął inne sytuacje skrajne, które nie wyznaczają żadnego z biegunów sporu, lecz sam spór unieważniają przez likwidację pojęcia plagiatu, a tym samym pośrednio - jakiejkolwiek oryginalności. Chodzi tu o nowelistykę Borgesa, kreatora monstrualnych dystopijnych alegorii wszechwiedzy i archetekstu, wyczerpującego wszystkie możliwości ludzkiej myśli i wyrażania. Argentyński klasyk fantastyki wyprzedził pomysły postmodernistów jako „założyciel” Biblioteki Babel, „odkrywca” Księgi Piasku i świadomości mieszkańców Tlönu, dla których

pojęcie plagiatu nie istnieje: ustalono, że wszystkie dzieła pochodzą od jednego tylko autora, ponadczasowego i anonimowego. ${ }^{5}$

5 J.L. Borges Tlön, Uqbar. Orbis Tertius, w: tegoż Fikcje, przeł. A. Sobol-Jurczykowski, St. Zembrzuski, Warszawa 2003, s. 27. 
Pisarz jest więc jedynie bibliotekarzem poszukującym gotowych tekstów, niekiedy sporządzającym ich niedokładne kopie, co zresztą oznacza przedsięwzięcie jałowe wobec absolutnej kompletności archiwum Wszechświata. Tego rodzaju wizje totalne oczywiście likwidują wszystkie zakresy i aspekty jakkolwiek pojętej własności intelektualnej, a tym samym zasadność istnienia prawa autorskiego, toteż jako parodystyczne hiperbole nie mogły posłużyć za argument w interesującym nas sporze; niemniej właśnie dlatego warto je w kontekście książki Jakubowiaka przywołać.

Filozofia i literaturoznawstwo sporu z prawem wokół autorstwa nie zakończą zapewne do końca świata, krytykując wytrwale kolejne akty normatywne i projekty ich modyfikacji. Czy kodyfikatorzy prawa kiedykolwiek odnajdą formułę adekwatną do zawiłości dylematów, zadowalającą tych, którym powinna służyć - można wątpić, ale powodem nie jest ani brak dobrych chęci z obu stron, ani bariery porozumienia, lecz nieprzekładalność języków. Prawo dąży do jednoznaczności rozstrzygnięć na terenie grząskim i rozmytym przez diachronię, toteż między „oryginalnością" a „plagiatem” usiłuje wytyczyć empirycznie niepodważalną cienką czerwoną linię tam, gdzie humanistyka widzi szarą strefę sporną i podlegającą nieustannym negocjacjom. Rozdźwięk wydaje się wyrazistym symptomem ogólnej aporii kultury, polegającej na tym, że subtelny humanistyczny relatywizm wydaje się nieprzekładalny na prawniczy idealizm i abstrakcję sztywnych reguł.

Wprawdzie badacz zajmuje się głównie kwestią plagiatu w dyskursie literackim, a tylko dygresyjnie wkracza także w krytykę instytucji nauki poddanej prawnej normatywizacji, szkoda, że zadowala się wnioskiem o niemocy kontroli antyplagiatowej, nie drążąc w tym dziś najbardziej drażliwym obszarze. Ciekawym tematem byłyby właśnie represyjne systemy, a wśród nich Otwarty System Antyplagiatowy, bo o trafności skrótu jego nazwy przekonał się już niejeden pokąsany autor. Warto byłoby sprawę przebadać i wyrazić jakąś opinię o systemie, gdyż niemal apologetyczne jego opisy w internecie stwierdzają, że jest narzędziem dość skutecznie sprawdzającym następstwo szeregu użytych w tekście słów (a nawet więcej), choć zarazem zastrzegają, że nie wychwytuje subtelniejszych związków intertekstualnych, toteż w ocenie oryginalności tekstu nie może zastąpić eksperta ${ }^{6}$.

$\mathrm{Na}$ koniec swoje rozpoznania w obszarze literatury Jakubowiak jednak odnosi - jakby mimochodem i nie dostrzegając dystynkcji - właśnie do praw i obyczajów obowiązujących w dyskursie akademickim. Zrozumiałe,

6 Otwarty System Antyplagiatowy, wiki.osaweb.pl (10.06.2018). 
że na ten temat wypowiada się powściągliwiej i zdawkowo, gdyż wkracza na grunt metanauki, tworząc pośrednio ryzykowny metatekst do swej rozprawy:

Z jednej strony od badaczy wymaga się możliwie pełnego rozpoznania literatury przedmiotu i odzwierciedlenia jej w aparacie przypisów i bibliografii. Z drugiej jednak strony stawia się przed nimi wymóg oryginalności - stworzenia nowej wiedzy, która wykracza poza wcześniejsze ustalenia. (s. 292)

Wybrzmiewa tu nieśmiało żal naukowca i apel o reakcję empatyczną, a ta może być dwojaka. Z jednej strony wskazaną opozycję da się wyostrzyć gorzkimi uwagami o pewnych koniunkturach badawczych i obłudnej promocji „kreatywności”. Także o tym, że publikacje naukowe są zawsze recenzowane przez innego uczonego, toteż ocalenie lub unicestwienie autorskiego „wkładu twórczego" zależy od elastyczności lub restrykcyjności oceny recenzenta i wydawcy, a w skrajnych przypadkach odkrycie bywa ocenzurowane. Ale to już temat na inną książkę, np. zatytułowaną Czy Kopernik zrobiłby habilitację z teorii heliocentrycznej?, być może odsłaniającą kulisy zinstytucjonalizowanej nauki w stopniu tak rewolucyjnym, że praca nie mogłaby się ukazać w normalnym trybie. Z drugiej strony można uznać, że „przypisowa” erudycja nie wyklucza oryginalności, bo elementy te są w dyskursie naukowym komplementarne, gdyż każde novum rodzi się na gruncie jakiegoś datum, a więc w tym wypadku rozterka badacza wydaje się bezprzedmiotowa. Zwłaszcza że dowodzi tego cała jego książka, w której znakomite interpretacje wynikają właśnie z rzetelnego przeglądu i mistrzowskiego skompilowania najciekawszych epizodów historii konfliktowego współżycia literatury i prawa.

$\mathrm{Na}$ koniec pozwolę sobie na refleksję autotematyczną. Pisząc w laptopie omówienie tej książki, roboczo zaznaczałem na niebiesko uwagi i glosy własne, na czarno zaś cytaty, parafrazy i streszczenia pracy Jakubowiaka. Eksperyment wykazał miażdżącą przewagę druku niebieskiego. Oczywiście nie dowodzi to żadnej autonomii mojego autorskiego wkładu w artykule, który z założenia jest metatekstem, czyli nie mógłby powstać bez lektury znakomitej książki ani nie może jej nijak zastąpić. Świadczy natomiast o doznanej sile inspiracji. 


\section{Abstract}

\section{Piotr Michałowski}

UNIVERSITY OF SZCZECIN

The Elusiveness of Inevitable Plagiarism

Review: M. Jakubowiak, Nieuchronny plagiat: Prawo autorskie w nowoczesnym dyskursie literackim [Unavoidable Plagiarism: Copyright in Modern Literary Discourse] (Wydawnictwo IBL PAN, Warsaw 2017).

\section{Keywords}

copyright, plagiarism, originality, textual theory, Maciej Jakubowiak 